\title{
HUBUNGAN KECERDASAN SPIRITUAL TERHADAP PRESTASI BELAJAR SISWA
}

\author{
Hasbi Ashshidieqy* \\ "IAIN Syekh Nurjati Cirebon \\ DOI: https://doi.org/10.21009/JPPP.072.02
}

Alamat Korespondensi:

hasbi.ashshidieqy@gmail.com

\begin{abstract}
Many people think that the highest intelligence among the other multiple intelligences is IQ intelligence. It's just that IQ intelligence is more often used in everyday life to get material, find solutions, and solve problems. The author assumes $S Q$ is the intelligence of the highest intelligence among multiple intellegence where $S Q$ is the inner intelligence of the mind and soul to build yourself into a whole person by always thinking positive in dealing with every incident that happened. Therefore, the authors assume that students who have spiritual intelligence will always be able to solve problems in education. The purpose of this study is as follows

(1) To know the nature of spiritual intelligence

(2) To know the essence of student achievement

(3) To know the relation of spiritual intelligence to student achievement.

The method used is descriptive correlational method is to describe the relationship of one variable with another variable to find conclusions in the form of a comparison. This method is used to take the results of a general picture of whether there is a positive or negative correlation.
\end{abstract}

\section{Keywords:}

spiritual intelligence, learning achievement

\section{Pendahuluan}

Pendidikan adalah pengaruh lingkungan atas individu untuk menghasilkan perubahan yang tepat di dalam kebiasaan tingkah lakunya, pikirannya dan perasaanya. (Godfrey Thompson, 1997:2) Pendidikan bukan hanya sekedar sekolah tapi lebih dari itu bisa menyentuh hati nurani dan menimbulkan perubahan pada sikap dan moral manusia. Pendidikan dilakukan secara sadar dan dilakukan secara totalitas, dalam artian seluruh pihak pasti bisa membawa pengaruh jalannya pendidikan. Pendidikan dalam arti sempit yaitu dengan belajar di Sekolah formal dimana peserta didik dibimbing dan diarahkan agar sesuai tujuan dari pendidikan itu sendiri. Sekolah menjadi hal yang penting karena semakin banyak tuntutan zaman dibutuhkannya SDM yang berkualitas dan memiliki keterampilan, serta memiliki spiritual yang baik. Untuk mencapai kesejahteraan sosial pun sebagian besar jalur yaitu dengan menempuh pendidikan terlebih dahulu. Untuk memecahkan berbagai masalah dalam pendidikan terhadap siswa, penulis berani mengedepankan kecerdasan spiritual sebagai solusi pertama.

Kecerdasan spiritual adalah kecerdasan tertinggi diantara multiple intelligence lainnya yakni dengan memuat seluruh kecerdasan lainnya dalam pendapat Dana Zohar dan Ian Marshall (2000) menjelaskan bahwa kecerdasan spiritual "is the necessery foundation for the efective functional of both IQ and EQ". Mereka berdua menegaskan bahwa tanpa kecerdasan spiritual menurut mereka merupakan kecerdasan tertinggi pada manusia, yang dilingkupi seluruh kecerdasan yang ada pada manusia. Artinya, kecerdasan spiritual melingkupi seluruh kecerdasan yang 
terdapat pada manusia (Safaria, 2007:15). Dengan kecerdasan spiritual manusia akan dibimbing dan diarahkan oleh kebijaksanaan yang ia dapatkan setelah memaknai arti kehidupan. Kecerdasan SQ akan membawa seseorang kepada pemahaman kehidupan. Seseorang yang memiliki kecerdasan spiritual akan lebih pandai menyikapi segala penderitaan kehidupan dengan emosi positif dan memaknai kehidupan. Hal ini menyebabkan orang yang memiliki kecerdasan ini akan selalu tepat menempatkan posisinya dalam menghadapi situasi apapun.

Dari kebijaksanaan yang didapat dalam menghadapi masalah mereka akan melihat dari berbagai sudut pandang serta makna yang terkandung didalamnya.

Prestasi belajar merupakan gambaran umum kemampuan siswa dalam menyerap pengetahuan yang dilakukan secara sadar. Prestasi adalah kemampuan kita untuk mencapai nilai tertinggi, sedangkan dengan nilai yang rendah maupun sedang tidak bisa diebut prestasi. Oleh karena itu dapat bisa menjadi sebuah kebanggaan siswa ketika mendapatkannya.

Tidak sedikit yang menganggap orang yang memliki IQ tinggi dapat memecahkan segala persoalan kehidupan. Namun dalam dunia pendidikan kerap terjadi fenomena dimana orang yang memiliki IQ tinggi tidak memiliki prestasi yang gemilang dibanding dengan temannya yang memliki IQ rata-rata. Adapula pemilik IQ tinggi dalam prestasi belajarnya tidak bisa mempertahankan rangking di kelas atau nilai terbaiknya. Termasuk pula tidak sedikit mahasiswa yang memiliki IQ tinggi ketika terjun ke dunia masyarakat mereka seolah-olah tidak terlihat eksistensinya bahkan ketika berkecimpung dalam dunia masyarakat kesuksesan kalah dengan mahasiswa yang biasa saja. Dengan demikian IQ bukanlah satu-satunya solusi terbaik untuk memecahkan berbagai problema di atas. Penulis beranggapan kecerdasan sosial lebih memberikan pengaruh lebih bagi peserta didik dimana kecerdasan spiritual yang baik mampu mengendalikan jiwa seseorang ke arah eksplorasi potensi diri sehingga mampu memberikan perubahan positif bagi siswa.

Oleh karena itu penulis ingin mengangkat sebuah topik dengan bahasan bagaimana korelasi kecerdasan spiritual terhadap prestasi belajar sehingga akan didapatkan hasil yang berguna sebagai referensi guru, dosen, maupun tenaga pendidik lainnya agar tercapainya tujuan pembelajaran dalam pendidikan.

\section{Hasil dan Diskusi}

\section{A. Kecerdasan Spiritual}

\section{a) Definisi kecerdasam spiritual}

Menurut Prijosaksono, kata spiritual memiliki akar kata spirit yang berarti roh. Kata ini berasal dari bahasa latin, spiritus, yang berarti bernafas. Selain itu kata spiritus dapat diartikan juga sebagai alkohol yang dimurnikan. Oleh karena itu spiritual dianggap suatu hal yang murni. Roh bisa diartikan sebagai energi kehidupan, yang membuat kita hidup, bernapas dan bergerak. Spiritual berarti pula segala sesuatu diluar tubuh, fisik kita, termasuk pikiran, perasaan, dan karakter kita (Kurniawati \& Abrori, 2005: 114-115).

Kecerdasan spiritual membicarakan tentang kemampuan manusia untuk mengenali potensi dirinya sebagai makhluk spiritual dengan mengangkat hakikat manusia untuk mengembangkan kemampuannya. Artinya dengan menghargai diri sebagai makhluk spiritual, yang hanya sebagian kecil dari semesta akan membuat seseorang yang memiliki kecerdasan spiritual menjadi pandai membimbing dirinya untuk menemukan tujuan hidupnya melalui hakikat manusia. Seorang yang tinggi SQ-nya cenderung menjadi menjadi seorang pemimpin yang penuh pengabdian - yaitu seorang yang bertanggung jawab untuk membawakan visi dan nilai yang lebih tinggi terhadap orang lain, ia dapat memberikan inspirasi terhadap orang lain (Zohar \& Marshal, 2001:14)

Zohar mendefinisikan kecerdasan spiritual lebih variatif, kecerdasan spiritual dianggap sebagai kecerdasan yang bersolusi untuk menghadapi dan memecahkan berbagai problema. Kecerdasan spiritual dapat pula dibutuhkan ketika seseorang buntu dalam menemukan solusi karena kecerdasan ini berbicara tentang seberapa mampu seseorang melihat sisi positif dari suatu peristiwa, dengan cara melihat persoalan dari berbagai sudut pandang. Oleh karenanya seseorang dapat menentukan solusi terbaik ketika pengidentifikasian keadaan sudah dilakukan.

Spiritual quotient dapat digunakan untuk menyatukan hal-hal yang bersifat interpersonal, 
dengan menghimpun emosi positif antar sesama dengan memunculkan sikap kebijaksanaan yang bersumber dari pemahaman kehidupan dan pengaktualisasi diri. Serta dapat menjembatani kesenjangan tiap-tiap individu melalu pendekatan afektif (perasaan) guna menumbuhkan emosi positif dalam kehidupan sehari-hari. Daniel Goleman telah menulis emosi-emosi yang digunakan untuk berhubungan dengan orang lain. Namun, EQ tidak menjembatani kesenjangan itu sedangkan SQ memberikan makna sejati, sebagaimana semua itu memberikan tempat sesuai porsinya pada dalam diri manusia.

Berbicara tentang kecerdasan spiritual pasti tidak akan pernah lepas dari kesadaran spiritual tiap individu. Kedua hal tersebut tidak akan terpisah dalam pengoptimalan kerja jiwa dalam memaknai dan memahami kehidupan. Sinetar (2001) menyebutnya sebagai kesadaran dini dimana individu umtuk secara terus menerus mengaktualisasikan diri itu membawanya. Ketika seseorang dapat memahami hakikat hidupnya maka kesadaraan spiritualnya akan menumbuhkan motivasi pada pencapaian yang utuh dan optimal.

Viktor Frankl (1973) menyebutkan bahwa dimensi spiritual (ruh) merupakan dimensi yang mengadakan bahwa kita adalah manusia. Dia menegaskan "man lives in three dimension, the somatic, the mental and spiritual". Frankl (1973) lebih lanjut menegaskan bahwa "three factor characterize humas existence, man spirituality, his freedom, and his responsibility". Oleh karena itu dimensi spiritual ini mencakup dimensi lainnya dan menjadi lahan yang cocok dalam pengembangan dimensi-dimensi lainnya pada diri seorang anak.

Spiritual quotient adalah implementasi diri kita terhadap kehidupan melalui jalur-jalur dengan integrasi diri. SQ tidak selalu berkaitan dengan ritual ibadah saja. ini dua hal yang berbeda. Tidak selalu yang rajin melaksanakan shalat atau pergi haji berulang-ulang itu akan meningkatkan kecerdasan spiritualnya. Memang dalam hal meningkatkan kecerdasan spiritual, ritual ibadahlah yang sering digunakan orang-orang pada umumnya untuk mengoptimalkan peranan jiwa manusia itu sendiri. Namun, ritual ibadah hanyalah salah satu metode guna meningkatkan kecerdasan spiritual guna memahami hakikat manusia secara menyeluruh untuk dimaknai oleh jiwa yang akhirnya menjadi sebuah acuan berfikir dalam memecahkan sebuah permasalahan.
Dengan demikian dapat kita pahami bahwa kecerdasan sosial merupakan pengembangan sempurna dari akal budi guna memikirkan hal-hal yang bersifat immaterial yang memancarkan energi batim sehingga terbentuklah motivasi lahirnya ibadah dan moral.

\section{b) Karakteristik Kecerdasan Spiritual}

Menurut Subandi, (2001) dalam artikelnya mengemukakan bahwa ciri-ciri di atas menurutnya masih terlihat sangat psikologis, padahal dimensi spiritual jauh melebihi hal itu, dia menambahkan beberapa kriteria yang lain yaitu:

1. Kemampuan menghayati keberadaan Tuhan.

2. Memahami diri secara utuh dalam dimensi ruang dan waktu

3. Memahami hakekat di balik realitas

4. Menemukan hakikat diri

5. Tidak terkungkung egosentrisme.

6. Memiliki rasa cinta

7. Memiliki kepekaan batin

8. Mencapai pengalaman spiritual: kesatuan segala wujud, mengalami realitas nonmaterial (dunia gaib).

Kecerdasan spiritual terlihat komplek, akan tetapi kecerdasan ini hanya membutuhkan kemamuan untuk membersihkan jiwa dari pengaruh buruk.

Dengan merujuk pada makna utama, penuilis mencoba untuk mendekripsikan karakter dari kecerdasan spiritual adalah sebagai berikut:

a. Memiliki tujuan hidup yang baik

Orang yang memiliki kecerdasan spiritual akan mengerti bagaimana hidupnya akan berlangsung. Selalu memaknai hidup dari sisi positifnya membuat seseorang yang spiritualnya baik akan menemukan tujuan hidup yang baik pula. Menurut Stephen R. Covey sperti yang dikutip Toto Tasmara dalam bukunya kecerdasan rohaniyah, visi adalah pengejawantahan yang terbaik dari imajinasi kreatif dan merupakan motivasi utama dari tindakan manusia.

Mereka sangat memikirkan tujuannya, bagaimana mencapainya hingga apa saja hal-hal kecil yang terkait dengan tujuannya. Seseorang yang memiliki kecerdasan spiritual yang baik akan memilih tujuan yang tepat dan dapat dipertanggung jawabkan baik secara moral maupun dihadapan Allah SWT. Dengan demikian kehidupan manusia bukan hanya makan, minum, tidur, dan sebagainya, tetapi lebih jauh dari itu 
manusia adalah makhluk yang membutuhkan tuhan. Mereka punya kebutuhan yaitu kebutuhan rohani seperti mendekatkankan diri kepada Allah SWT bagi seorang muslim. Dimana seorang muslim akan mendapatkan ketenangan dan ketentraman jiwa ketika dapat melaksanakan ritual ibadahnya. Diantara manfaat tujuaan hidup adalah:

- Mendorong untuk berfikir lebih mendalam

- Membantu memverifikasi pikiran-pikiran terdalam

- Memperluas cakrawala pandangan

- Membantu mengarahkan kehidupan seseorang

- Membantu mengeksploitasi potensi yang ada pada diri.

b. Memiliki prinsip hidup

Prinsip adalah suatu kesadaran berpegang teguh kepada acuan berfikir yang esa. Dalam menjalani kehidupan kita membutuhkan prinsip yang akan mengarahkan dan membimbing kita. Kekuatan prinsip kita akan menentukan jalan mana yang kita pilih, apakah jalan yang benar atau jalan yang salah. Tergantung kita dalam memegang prinsip itu sendiri. Seperti dalam surat Asy-syams (91) 8-10.

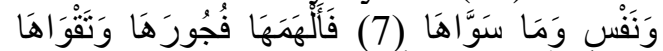

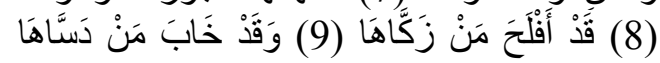

Demi jiwa dan penyempurnaan (ciptaannya), maka Allah mengilhamkan kepada jiwa itu (jalan) kefasikan dan ketakwaannya, sesungguhnya beruntunglah orang yang menyucikan jiwa itu, dan sesungguhnya merugilah orang yang mengotorinya. (Q. S. Al-Syams [91]: 7-10).

Dari ayat di atas kita bisa simpulkan bahwa Allah telah memberi kita kehendak tentang apa yang kita pilih beserta info konsekuensinya. Tinggal bagaimana kita memilih menggunakan prinsip yang kita punya dengan memperhitungkan segala pertimbangkan disertakan tanggung jawab kita dihadapan Allah.

c. Selalu merasakan kehadiran Allah

Orang yang memiliki kecerdasan spiritual baiasanya akan selalu merasakan kehadiran Allah. Mereka merasa selalu berada dalam pengawasan Allah kapanpun dan dimanapun. Sehingga akan lahir pribadi yang tanggung, berkualitas dan komitmen menjaga prinsip yang esa. Untuk mencapai tahap seperti itu bukan tiba-tiba muncul begitu saja, akan tetapi ada proses pembersihan jiwa yang dilakukan dengan cara memperbanyak ibadah kepada Tuhan.

\section{d. Cenderung kepada kebaikan}

Seseorang yang memiliki kecerdasan spiritual akan selalu menghargai dirinya baik jasmaninya atau rohaninya. Selalu kritis dan berhati-hati dalam tindakan serta selalu termotivasi untuk melakukan kebaikan.

e. Berjiwa besar

Setiap orang memiliki ego tetapi kadar ego terhadap suatu hal tetap kita yang tentukan. Manusia dengan spiritual yang baik akan selalu mudah menerima kebenaran. Ia akan selalu bermuhasabah tentang dirinya, lapang dada mementingkan kepentingan umum dibanding kepentingan pribadi, serta sportif dan sering meminta maaf ketika melakukan kesalahan.

\section{f. Memiliki empati}

Dengan spiritual yang baik seseorang akan selalu memiliki perasaan senang jika dapat membantu orang lain dan merasa sedih ketika seseorang tersebut tidak dapat membantu seseorang. Analogi ini sangat tepat untuk menggambarkan seseorang dengan perasaan yang halus sebab memiliki kecerdasan spiritual. Dengan perasaan yang lembut seseorang dengan spiritual yang baik akan mudah tersentuh melihat penderitaan orang lain, memliki kepedulian yang luar biasa terhadap sesama manusia dan bersimpati kepada keadaan sekitar.

Dengan demikian banyak manfaat ketika seseorang mampu memiliki kecerdasan spiritual yang mencakup seluruh multiple intellegence. Seseorang tersebut akan memiliki tujuan yang terstruktur dengan baik dan hidup dengan prinsipprinsip yang diteguhkan kepada Allah SWT semata. Serta mampu merasakan penderitaan sesama manusia dan tergerak hatinya untuk membantu sebagai bentuk kepedulian. Setiap apa yang dilakukan akan berbentuk ibadah dalam rangka rutinitas pembersihan jiwa, guna menjadi manusia seutuhnya.

c) Komponen Kecerdasan Spiritual

Selain Zohar, menurut psikolog asal University of California, Davis, Robert Emmons, komponenkomponen kecerdasan spiritual adalah sebagai berikut:

1. Kemampuan mentransendensi, orang-orang yang sangat spiritual menyerap sebuah realitas yang melampaui materi dan fisik.

2. Kemampuan untuk menyucikan pengalaman sehari-hari. Orang yang cerdas secara spiritual

Jurnal Penelitian dan Pengukuran Psikologi, Vol. 7, No. 2, Oktober 2018 
memiliki kemampuan untuk memberi makna sakral atau illahi pada berbagai aktivitas, peristiwa dan hubungan sehari-hari

3. Kemampuan untuk kondisi-kondisi kesadaran puncak. Orang yang cerdas spiritual mengalami ekstase spiritual. Mereka sangat perspektif terhadap pengalaman mistis.

4. Kemampuan untuk menggunakan potensipotensi spiritual untuk memecahkan berbagai masalah. Transformasi spiritual seringkali mengarahkan orang-orang untuk memprioritaskan ulang sebagai tujuan.

5. Kemampuan untuk terlihat dalam berbagai kebajikan (berbuat baik). Orang yang cerdas spiritual memiliki kemampuan lebih untuk menunjukan pengampunan, mengungkap rasa terima kasih, merasakan kerendahan hati, dan menunjukkan rasa kasih (Iwan Joyo, 2017).

\section{B. Prestasi belajar}

a) Definisi prestasi

Dari batasan kajian para ahli dapat disimpulkan bahwa belajar adalah kegiatan yang dilakukan prestasi

Prestasi adalah hasil yang telah dicapai seseorang dalam melakukan kegiatan (Gagne, 1985:40) menyatakan bahwa prestasi belajar dibedakan menjadi lima aspek, yaitu: kemampuan intelektual, strategi kognitif, informasi verbal, sikap dan keterampilan. Prestasi dapat diartikan pula sebagai sebuah kecakapan atau hasil nyata dari usaha dalam kurun waktu tertentu.

b) Pengertian belajar

Ada beberapa pendapat para ahli Cronbach, Harold Spears dan Geoch dalam (Sardiman A.M, 2005:20) sebagai berikut:

1. Cronbach memberikan definisi:

"Learning is shown by a change in behavior as a result of experience".

"Belajar adalah memperlihatkan perubahan dalam perilaku sebagai hasil dari pengalaman".

2. Harold Spears memberikan batasan:

"Learning is to observe, to read, to initiate, to try something themselves, to listen, to follow direction".

Belajar adalah mengamati, membaca, berinisiasi, mencoba sesuatu sendiri, mendengarkan, mengikuti petunjuk/arahan.
3. Geoch, mengatakan :

Learning is a change in performance as a result of practice".

Belajar adalah perubahan dalam penampilan sebagai hasil praktek.

Dari definisi belajar adalah usaha secara sengaja yang menimbulkan sebuah perubahan, baik sikap maupun perilaku ke arah yang lebih baik. Belajar bukan hanya dalam ruang lingkup sekolah sekolah saja, tetapi ketika seseorang bisa mengubah perilaku maupun sikap kapanpun dan dimanapun serta mampu mengoptimalkan potensi maka secara tidak langsung telah mencapai tujuan dari belajar itu sendiri. Belajar bukan hanya verbalistik guru terhadap murid, akan lebih baik ketika murid atau peserta didik dapat meniru teladan baik sang guru dengan kinestetik atau pengaplikasian pengetahuan.

\section{c) Pengertian prestasi belajar}

Dalam dunia pendidikan kita juga harus memperhatikan input, truput, output, dan evaluasi. Dalam evaluasi atau penilaian pembelajaran memuat prestasi belajar. Adapun pendapat para ahli mengenai definisi prestasi belajar adalah sebagai berikut:

- Sumadi Suryabrata, Prestasi Belajar adalah nilai sebagai rumusan yang diberikan guru bidang studi mengenai kemajuan atau prestasi belajar selama masa tertentu (Suryabrata, 1998).

- Siti Pratini, Prestasi Belajar adalah suatu hasil yang dicapai seseorang dalam melakukan kegiatan belajar (Pratini, 2005).

- WS.Winkel, Prestasi belajar merupakan hasil belajar yang ditampakkan oleh siswa berdasarkan kemampuan internal yang diperoleh sesuai dengan tujuan instruksional (Winkel WS, 1989).

Dari uraian di atas bisa kita simpulkan bahwa prestasi belajar adalah sebuah hasil dari proses pembelajaran yang dibatasi oleh kurun waktu tertentu. prestasi belajar bisa diartikan pula sebagai pengukuran kemampuan peserta didik dalam menyerap materi yang diberikan oleh pendidik. Sudah menjadi kewajiban peserta didik harus belajar guna mengembangkan potensi yang dimiliki. Dengan evaluasi berbentuk prestasi siswa dalam belajar kita dapat mengetahui sejauh mana kesungguhan siswa dalam belajar dan dapat memantau perkembangan pemahaman materi

Jurnal Penelitian dan Pengukuran Psikologi, Vol. 7, No. 2, Oktober 2018 
siswa. Menurut Sia Tjundjing belajar dapat diartikan sebagai perubahan tingkah laku yang relatif menetap sebagai hasil pengalaman dan latihan (Tjundjing, 2001: 70).

Belajar merupakan suatu proses perubahan yang bisa dilakukan dengan cara membaca, menulis, menghitung, meniru dan sebagainya dengan syarat perubahan ke arah yang baik disertakan bimbingan dan arahan dari pendidik. Selaras dengan pendapatpendapat di atas, (Hakim, 2000: 1) mengemukakan bahwa belajar adalah suatu proses perubahan di dalam kepribadian manusia, dan perubahan tersebut ditampakkan dalam bentuk peningkatan kualitas dan kuantitas tingkah laku seperti peningkatan kecakapan, pengetahuan, sikap, kebiasaan, pemahaman, keterampilan, daya pikir, dll.

Prestasi belajar dapat menyimpulkan dengan berupa angka atau huruf yang berupaya untuk menggambarkan perkembangan peserta didik. Dalam meraih prestasi belajar bukan hal yang tibatiba kita bisa meraihnya sewaktu-waktu, tetapi ini tentang perjuangan dan menghargai proses belajar itu sendiri.

\section{d) Kecerdasan Spiritual dalam Prestasi Belajar Siswa}

Spiritual sangat berpengaruh dalam kehidupan kita, spiritual mampu memecahkan permasalahan dengan solusi yang didapat dari kebijaksaan hidup. Seseorang yang memiliki spiritual yang baik akan menjalani kehidupan ini dengan terpola dan tujuan hidup yang jelas, sehingga baik dalam aspek manapun kecerdasan spiritual akan selalu berguna untuk menuntun seseorang pada kebahagiaan yang hakiki. Ketika pembersihan jiwa dilakukan setiap saat seperti melalui ritual ibadah, maka seseorang yang memiliki kecerdasan spiritual akan lebih bisa menghargai hidup kita dan mengetahui potensi dalam dirinya. Ketika jiwa seseorang telah baik dan optimal digunakan maka apapun yang dilakukan dalam menjalani kehidupan semuanya berorientasi kepada satu titik yaitu sebagai bentuk penghambaan kepada Allah SWT.

Dalam pendidikan formal, spiritual yang baik sangat diperlukan bagi peserta didik. Sehingga budi pekerti yang baik dapat tertanam sejak dini. Ketika sang anak mampu mengkomparasikan seluruh multiple intelligence yang dia punya, anak akan merasakan perbedaan antara belajar biasa dibanding belajar dengan pengoptimalan spiritual terlebih dahulu. Anak akan memahami statusnya sebagai seorang pelajar dan segera membuat capaian-capaian pembelajaran serta konsep dalam belajar. Hal ini dikarenakan jika seseorang yang memiliki kecerdasan spiritual maka ia akan dapat melihat sisi positif dari seluruh situasi. Dengan demikian ia akan selalu berpikir setelah melakukan hal yang kurang maksimal dalam pencapaian tujuan instruksional. Anak akan mudah menyerap materi ketika memiliki kecerdasan spiritual karena dengan kecerdasan spiritual akan menuntun seseorang memiliki pikiran yang jernih dan memiliki jiwa yang besar sehingga ketika menerima materi, kepribadian anak selalu merasa tidak puas dengan pengetahuan yang sudah ada. Sehingga tujuan intruksional dalam pembelajaran akan selalu terlaksana karena anak selalu dalam keadaan siap menerima materi. Dengan demikian ada relasi yang baik ketika seseorang memiliki kecerdasan spiritual.

\section{Kesimpulan}

Kecerdasan spiritual sangat berpengaruh dalam prestasi belajar peserta didik. Dari seluruh multiple intelligence yang ada kecerdasan spiritual adalah kecerdasan yang mewakilinya dan mencakup seluruh aspek kehidupan. Karena kecerdasan spiritual ini sangat cocok digunakan peserta didik dengan fungsi sebagai pembersihan jiwa sekaligus sikap. Dari uraian pembahasan di atas sedikitnya telah kita dapatkan hubungan kecerdasan spiritual dengan prestasi belajar. Adanya korelasi positif antara kecerdasan spiritual dengan kecerdasan spiritual. Semakin baik kecerdasan spiritual maka semakin mudah dan terarah peserta didik dalam mengembangkan prestasi belajar. Perbandingan lurus ini dapat digunakan sebagai acuan dalam pemahaman kepada peserta didik.

\section{Daftar pustaka}

Al Marsudi, S. (2001). Pancasila dan UUD 1945 dalam Paradigma Reformasi, Jakarta: PT. Raja Grafindo Persada

Frankl, V. E. (1973). (In R. \& C. Winston, Trans.) The Doctor and the Soul: From Psychotherapy to Logotherapy. New York: Vintage Books 
Gagne. (1985). Prestasi belajar. (online) tersedia: http://sunartombs.wordpess.com/2009/01/0 5/pengertian-prestasi-belajar/

Joyo, I. (2009). Pentingnya ESQ dalam Manajemen Konflik Bagi Perawat. (hhtp://www.echinstitute/opini_kecerdasan _emosional_spiritual,diak ses 10 Desember 2009)

Kurniawati, E \& Abrori, L. (2005). Korelasi SQ dengan kinerja pada Karyawan pada Karyawan UIN Malang. Malang: Psikoislamika.

Pratini, S. (1980). Psikologi Pendidikan. Yogyakarta: Studing

Sardiman, A.M. (2005). Interaksi dan Motivasi Belajar. Jakarta: Rajawali Press

Triantoro, S. (2005). Interpersonal Intelligence: Metode Pengembangan Kecerdasan Interpersonal Anak. Yogyakarta: Amara Books.
Tjundjing, S. (2001). Hubungan Antara IQ, EQ, dan QA dengan Prestasi Studi Pada Siswa SMU. Jurnal Anima. Vol. 17 no 1

Sinetar, M. (2001). Spiritual Intelligence. Jakarta: Bumi Aksara

Thomson, G. (1977). Dasar Konsep Pendidikan Moral. Jakarta : ALFABET

Winkel, W.S. (1989). Psikologi Pengajaran. Jakarta: Gramedia

Zohar, D. \& Marshall, I.N. (2000). SQ: Spiritual Intelligence: The Ultimate Intelligence. Great Britain: Bloomsbury.

Zohar, D. \& Marshall, I.N. (2001). SQ: Memanfaatkan Kecerdasan Spiritual Dalam Berpikir Integralistik dan Holistik untuk Memaknai Kehidupan. Bandung: Mizan

Jurnal Penelitian dan Pengukuran Psikologi, Vol. 7, No. 2, Oktober 2018 